\section{US research contracts}

\section{Small may mean nuisance}

\section{Washington}

MANY research institutions in the United States are expressing concern at a recent patent law requiring them to give preference to small businesses when licensing inventions arising from federally-supported research. One complaint is that many research universities are ill-equipped to evaluate the commercial strength of a small company eager to develop a potentially lucrative invention. And, according to draft regulations, would-be licensees who believe they have been treated unfairly can call for an investigation by the US Department of Commerce, raising the fear of harassment in research institutions.

The requirement that federal research contractors (other than large companies) must give small businesses first choice of patent-worthy inventions is encoded in public law 98-620, signed by the President in November last year, which gave the Department of Commerce responsibility

\section{New US-Soviet links}

\section{Washington}

THE National Academy of Sciences delegation to Moscow last week reached a quick agreement with the Soviet Academy on a two-year cooperative agreement restoring many of the exchange programmes suspended by the National Academy in 1981 in protest against the internal exile of Dr Andrei Sakharov. A draft protocol signed by both delegations at the end of two days of meetings specifically calls for future cooperation to be in "forefront fields" of science in which both the United States and the Soviet Union are advanced. Those who will participate in these programmes, which are to include joint workshops and exchange visits, will have to be approved by both sides. These stipulations seem intended to answer past criticism that the Soviets avoid sharing the work of their best scientists, especially in fields such as mathematics where they may hold an edge over the United States.

The actual fields to be included under the new agreement have yet to be decided; each side proposed a dozen topics last week, but the US academy has declined to provide further details pending the completion of sensitive negotiations that are expected to lead to a final agreement within a few months.

A short statement released by Frank Press, the president of the National Academy, who led the delegation, made only a fleeting reference to the issue of Sakharov: "Our discussion also covered what constitutes a propitious climate for cooperation... This climate naturally includes our concern about human rights." Stephen Budiansky for administering the law and for producing regulations. The draft regulations now being circulated are nevertheless softer than some had feared: contractors are required only to use "efforts that are reasonable under the circumstances" to attract small business licensees, although the requirement to prefer a qualifying small business applicant remains. In practice, this means that in cases where no small business is likely to be able to take on development, for example of a potential new drug, the search need be only a formality.

Norman Latker, director of the federal technology management division at the commerce department, says the department "has not placed all that much emphasis" on the need to seek small businesses, and the law has been "viewed as a statement of wish". The department has stopped short of placing on research contractors a requirement to demonstrate that reasonable efforts have been made.

At one stage, it was feared that an unfavourable ruling following a complaint of unfair practice to the commerce department would mean that contracts with large companies would have to be cancelled. It is now clear, however, that the department will investigate only general licensing procedures and will not intervene in specific cases.

The public law 98-620 changed markedly during its passage through Congress. It was originally an attempt to extend to large companies the rights previously enjoyed by small businesses and universities to take out patents on invention arising from federal grants and contracts. In the event, there was political opposition in Congress and large companies now negotiate separately over patent rights with the federal agencies. But the provisions of the bill originally intended to give small businesses crumbs from bigger tables, applying also to universities, have survived.

Some provisions of 98-620 are, however, viewed as liberating. Major institutions owned by the government but operated by contractors, such as the Stanford Linear Accelerator Center and the Jet Propulson will henceforth have the same first rights to patents arising from their research as independent contractors. Institutions in this category, which are owned mainly by the Department of Energy, also include Los Alamos, Lawrence Livermore and Argonne National Laboratories. And in another change, exclusive exploitation agreements with large companies will in future be permitted to extend up to the full 17-year lifetime of the patent. There had previously been an upper limit of five years from commercial availability of the product or 8 years from the date of the licensing agreement, a restriction that came to be viewed as an impediment.

Tim Beardsley
British research councils

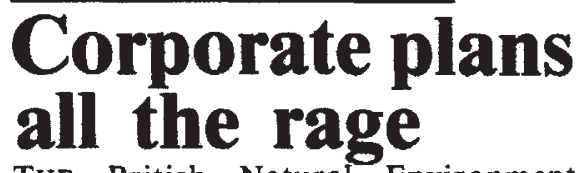

THE British Natural Environment Research Council (NERC) has come in for criticism over its handling of its own corporate plan - its proposals for structuring the next five years of its activities. The leaking of details of a draft version has resulted in a flood of letters to council members from interested parties. The outcome of a council meeting last Thursday is an unscheduled meeting called for this week which is expected to ratify a final draft for public release on 14 February.

There are three substantive issues involved in the proposed reorganization: centralization of control of the research institutes, the scale of staff cuts and the transfer of funds to support research in universities. NERC is adamant that the principles of the changes are already firmly established (and indeed were approved by the council last year), but that detailed modifications can still be incorporated in the light of opinion. The research council sees the corporate plan as a framework for future developments that will evolve during this coming financial year. There is still dissent amongst those who have discussed the document over the methods to be used to achieve the reorganization, but all parties do agree that fundamental change is necessary.

The problem is exemplified by the position of the British Geological Survey (BGS) as described by Professor J. Sutton of Imperial College in a recent speech critical of NERC. BGS is the only national survey under the aegis of a research council and stands in odd contrast with the Ordnance Survey (concerned with topographical maps), which comes directly under the Ministry of Defence. Elsewhere, in the United States, for instance, both topographical and geological mapping are functions of the geological survey of the Department of the Interior. As Sutton said, the comparable size of BGS and its parent body NERC causes problems with the result that senior members of BGS feel that independence is a viable alternative to the centralized direction now proposed.

One council member favourable to the plan said this week that geology has changed, with many important functions such as seismic surveying and mapping of the ocean floor requiring cooperation between BGS and, for example, the Institute of Oceanographic Sciences. Both are now components of NERC, and there is support on the council for this to continue, whatever reorganization takes place. Many prominent members of the British earth sciences community are calling for a return of BGS to its "proper" role as a national survey, providing and revising geological maps and a synthesis of the British geology.

Peter Gambles 